\title{
XLVII. Memoir upon living and fossil elephants
}

\section{Cuvier}

To cite this article: M. Cuvier (1807) XLVII. Memoir upon living and fossil elephants, Philosophical Magazine Series 1, 26:104, 302-313, DOI: 10.1080/14786440708563678

To link to this article: http://dx.doi.org/10.1080/14786440708563678

$$
\text { 册 Published online: } 18 \text { May } 2009 .
$$

Submit your article to this journal

LII Article views: 2

Q View related articles $\asymp$ 
0.787 of azote, and 0.03 of carbonic acid. We ourselves had occasion to verify this grand law of nature in a journey we made to the Alps last year. The atmospheric air, analysed in places the most distant from each other, in deep valleys and on high mountains, on the banks of the lake of Geneva and at Neufchatel, in the glacieres of Chamouny, at Col de Baume, in the Valais, upon the great St. Bernard, at Turin, and at Grenoble, always presented to us the same composition. But since we have found that the refractive power of the air corresponds to that of the constituent principles which compose it, and that it may be deduced from them exactly, it also results from this fact, that this refractive power is the same over all the world at equal censities; and thus the tables of refraction, calculated by the geometricians and the astronomers of Europe, may extend, without modification, to all the countries in the world, provided that the refractive power of the air is not changed by the effects of heat : this is what the experiments we purpose making this summer will enable us to decide.

"In the present memoir we have endeavoured to present to natural philosophers and to chemists some useful results founded upon scrupulous calculations and precise observations. We have endeavoured to determine, by direct experiments, all the physical facts which serve as the foundation of the theory of the atmospheric refractions, and which hitherto had been concluded from observations. In this respect we have it particularly in view to answer the questions proposed by the author of the Mécanique Céleste in his tenth book, and to fix the points to which he had called the attention of philosophers."

XLVII. Memoir upon living and fossil Elephants. By $M$. Cuvier.

[Concluded from p. 211.]

ThE British islands, which from their local situation do not seem to have ever had any living elephants, present us with a great number of fossil ones. 
Sloane possessed a tusk, dug up from a bed of gravei in Gray's-inn-lane, London, 12 feet below ground. He had another, also, from the county of Northampton, found in blueisb clay, below layers composed of 14 inches of vegetable earth, and 30 of flint mixed with earth *.

A grinder from the same, and of 14 laminæ, was found further down, being under 16 feet of vegetable earth, 5 feet of sandy earth mixed with flint, 1 foot of black sand mixed with small stones, 1 foot of small gravel, and 2 feet of large gravel, where the tooth was, and below it alone was found blue clay $t$.

In the year 1630 a portion of a cranium was found at Gloucester with some teeth; and a lower grinder has been dug up at Trentham, in the county of Stafford $\ddagger$.

In 1700 several very large bones, one of them a humerus, were dug up at Wrebness, near Harwich, upon the river Stowre, 15 or 16 feet below the surface, in a bed of gravel $\$$.

At Norwich, in the county of Norfolk, in the year 174.5, there were found a grinder weighing 11 English pounds, and several large bones $\|$.

I have myself at this moment before my eyes, owing to the kindness of M. G. A. de Luc, the metacarpal bone of a little toe of the right fore foot, found at Kew, 18 feet below ground, "one foot and a half of which was composed of mould, 5 feet of reddish sandy clay, very fit for making bricks of ; 8 feet of siliceous gravel, and 3 feet of reddish sand, which rests upon clay. This sand contained many other ossifications : among others, the nucleus of a horn of the ox kind; and in another pit, in the same field, there was found a tusk, which broke upon being taken out. The clay contained shells, and annong others some nantili $q$.

The small island of Sheppy, at the mouths of the Thames and Medway, furnished a vertebra, a femur, a tusk, \&c. in a place washed by the tide**.

* Natural History of Northamptonshire, by Morton, p. 252. $\quad+$ Ibid.

$\ddagger$ Plot's History of Staffordshire. $\quad$ S Phil. Trans. vol. xxii. no. 274 .

11, Phil. Trans. vol. xlv. art. xxi.

These details are extracted from a letter with which I was favoured by 1. de Lne, dated Geneva, December 6, 1805 .

* Phil. Trans, vol, xlviii. p. 626,627. 
Mr. Peale mentions, still more rccently, some bones found in Salisbury Plain, near Bristol, and in the Isle of Dogs *. Dom Calmet, in his Dictionary of the Bible, speaks of a giant found in the neighbourhood of Salisbury, near the famous Stouehenge.

Pennant procured two grinders and a tusk from Flintshire. They were extracted, by some miners, from under a lead mine 118 feet deep, in a bed of gravel; and among the upper layers there was one of calcareous stone 10 or 12 feet thick: a stag's horn was found along with them. I suspect much that this position has not been well described; it is, perhaps, the only one of its kind.

Ireland has furnished elephant bones in its southern parts. There were four fine jaw-bones dug up in 1713 at Magherry, eight miles from Beltarbet, in digging the foundations of a mill $\uparrow$.

Scandinavia, although extremely unfit to breed living elephants, contains plenty of fossil ones.

M. Quensel, superintendant of the cabinet of natural history of the Academy of Sciences at Stockholm, has had the goodness to send me the drawing of a large lower jaw in the above cabinet: $i t$ was found in a hillock of sand, near the river Jic, in Ostrobothnia.

J. J. Dobeln has already described some gigantic bones dug up, in 1733, at Falkenberg, in the province of Halland. To judge of them from the drawings, they must be a first rib, a metacarpal bone, and a nondescript bone of an elephant.

The giants' bones dug up in Norway, spoken of by Pontoppidan in his Natural History of Norway, must be nothing else than elephants' bones.

Thomas Bartholin speaks of an elephant's jaw-bone which was sent from Iceland to Resenius, and given by the latter to the cabinet of the university of Copenhagen. It was petrified into silex.

Sloane had some in his cabinet altered in the same manner; but he has not informed us of the cause of it.

* Historical Disquisition on the Mammoth, p. 7. Note.

t Phil. Trans. vol. xxix. no. 349 .

Pontoppidan 
Pontoppidan also mentions after Torfers a crasinum and a tooth found in Iceland of a prodigions size.

Of all the countries in the world, the rast empire of Russia contains the greatest quantities of fossil bones, particularly in those provinces where we might least expect 10 find them, the frozen regions of Siberia.

Russia in Surope contains great quantities in several places; an immense quantity was found in 1775 at Swijatowski, 17 wersts from Petersburg.

There is in the Petersburg cabinet a ansk from the neighbourhood of Archangel, in the valley of the Dwina. Corneille le Brun mentions some tusks found near the surface of the ground at Vorones upon the Tanais. There is an immense collection of them, as wall as of the bones of various other animals, upon the banks of the Tanais, neas the town of Kostyusk.

M. Pallas, in his recent travels through the sointiern provinces of Russia, mentions several places between the Tanais and the Wolga; particularly the environs of Pensa, and two other places nearer the Wolga.

As to Asiatic Russia properly so called, the testimony af travellers and naturalists agrees in representing that region as swarming with fossil elephants.

This phænomenon is so general there, that the inhabitants have invented a fable to explain it; and they tell wh that these bones and tusks belong to a subterraneons animal hiving in the manner of the mole, but never being permitted to see the light of day. They have named this animal mamoment, or mammouth according to some, frum the word mamma which signifies earth in some Tartar idioms; accorsting to others, from the Arabian word lehemoth, employed in the book of Job for a large unknown animal, or mehemoth, an epithet which the Arabs are accustomed to add to the name of elephant $(f i h l)$ when it is very large.

They describe the tusks tound in Russia by the appellation of mammont horns (mammonto vaknst): these tusks are so numerous and so well preserved, particularly in the southern parts, that they are employed in the same manner as fresh ivory; and they form an article of commerce so im-

Vol, 26. No. 104, Jan, 1807. U

portant, 
portant, that the czars formerly reserved the monopoly of it to themseives.

It was the profit they produced which perhaps excited the searching for them, and which occasioned the discovery of so many of these bones in that vast country; adding to these circumstances, that the immense rivers which run into the Frozen Sea, and which are prodigiously swelled at the time of a thaw, and carry away large portions of their banks; and thus every year immense quantities of bones are discovered, besides those which are found in digging wells, \&c.

We ought not to believe that these animals have been simply led from India by the rivers of the neighbouring mountains, because this would still take place at the present day, as lately observed by a respectable author*.

M. Pallas informs us that there is not in all Asiatic Russia, from the Don or the Tanais to the extremity of the promontory of the Tchutchis, any brook or river upon the banks or beds of which elephants' bones, and those of other animals foreign to the climate, have not been found.

But the higher regions, and the primitive ana schistous chains of mountains, want them, as well as marine petrifications, while the lower declivities and the vast sandy plains furnish them wherever they are intersected by brooks or rivers, which proves that they would be found in abundance in the rest of their extent also if dug for.

There is but very few elephants' bones in such places as are low and marshy: thus the river $\mathrm{Ob}$, which flows sometimes through low and marshy forests, only contains them in such places " ubi adjacentes colles arenosi præruptam ripam efficiunt." Strahlenherg made the same observation several years ago upon the mauner in which these bones are brought to light in consequence of inundations.

They are found in every latitude, and it is from the north that the best ivory conies, because it has been less exposed to the action of the elements.

A circumstance which, independently of this prodigions

* Patrin Hist. Nat. des Mineraux, tom. v. p. 391, et sequent. : also Nouyeau Dict. des Sc. Nat., art. Fossiles.

abundance, 
abundance, excludes every idea of expeditions conducted by men is, that in some places these bouses are mixed with an innumerable quantity of bones of other savage animal's large and small.

What is still more remarkable is, that they are often found in beds filled with marine bodies, sach as sbells, \&ce. The above is an extract of the details of M. Pallas.

One particularity not less striking than any other related to us by this great naturalist is, that in some places eleptrants' bones have been found having still some fragments of flesh attached to them. The general opimion of the people of $\mathrm{S}_{-}$beria is, that mammonts have been dug up covered with skin and flesh, and still bleeding: this is an exaggeration; but it arises from the circumstanoe of the flesh being sometimes found preserved by the frost.

Isbrand-Ides speaks of a head the flesh of which was putrid, and of a frozen foot as large as a man of middling stature: and Jean-Bermbard Muller speaks of a tusk the cavity of which was filled with a matter resembling clotted blood.

We might, perhaps, doubt these facts if they were not confirmed by one of the same kind extremely well atohenticated, that of the entire and complete shinoceros dug up near Vilhorci, in 1771 , with all the flesh, skin, and hair belonging to it. We are indebted to M. Pallas for a circumstantial description of this phrenomenon; and the head and feet of it are still preserved at Petersburgh. These facts prove that it must have been a sudden revolution which had buried these astonishing monuments of antiquity.

To these general remarks we shall subjoin a cursory view of the principal places in Russia where fossil bones have heen discovered.

We have already mentioned those found in the beds of the Wolga; we may add those between the Volga and the Swiaga, and those along the banks of the Kama, where they are mixed with marine shells ; those of the river Irguis, and the bones given by M. Macquart to the Council of Mines, which are mixed with rhinoceros" ones.

It was also from the Wolga, without doubt, that the fe$\mathrm{U} 2$ mur, 
mur, brought from Casan by the astronomer Delille, and described by Daubenton*.

M. Pallas gives a long list of bones, tusks, and elephants' and rhinoceros' teeth sent from the government of Casan to Petersburgh in 1776 and $17 \% 9$, and which also come from the banks of the Swiaga.

The French journals recently contained an account of a complete skeleton found in the territory of Struchow, in the government of Casan.

The beds of the $\mathrm{Ob}$ are full of them. The people of $\mathrm{Sa}$ moieda bring great quantities of them continually for sale at Beresova: they collect them in the immense naked plains which extend to the Frozen Sea, and which are also filled with shells. There is an immense heap of bones at Kutschewaskoi, upon the $\mathrm{Ob}$.

The Irtisch, one of the principal branches of the $\mathrm{Ob}$, is perhaps the river which has afforded the most; as well as its tributary rivers, the Tobol, the Toura, and the Isette. The two latter, which descend from the eastern range of the Oural mountains, often afford these bones mixed with marine productions.

Strahlenberg speaks of an entire head, of four feet and a balf long, brought from Tumen upon the Toura. The Tom, another tributary of the $\mathrm{Ob}$, has furnished plenty of them, as well as the Keta.

An entire skeleton has been found upon the banks of the former, between Tounsk and Kafnetsko, by Messerschmidt.

Fossil bones have been found upon the Alei, and even at the foot of these mountains so rich in mines, from which several branches of the $\mathrm{Ob}$ derive thcir source. M. Pallas asserts that there was a grinder taken from a mine in the famous mountain of the Serpents, and found along with some antient marine productions.

The beds of the Jenissca has furnished them at all times mear Krasnojark, whence M. Pallas received a grinder. They are to be found even so far north as the 7oth degree of north latitude, below Selakino, that is to say, very near the Frozen

- Mem. de l'Acad, for 1762.

Sea. 
Sea. The above naturalist also names the Angara, otherwise called the Great Tombuska, among the rivers where they have been dug up. Messerschmidt and Pallas mention the Chatanga also, a river which falls into the Frozen Sea between the Jenissea and the Lena. Isbrand-Ides and Jean Bernhard Muller mention Jakutsk, upon the Lena; and the Academy of Petersburgh is in possession of a rhinoceros' cranium found not far from the mouth of this river, with almost the whole skeleton.

The Vilhoui, which falls into the Lena, and upon the banks of which this wbole rhinoceros was found, is certainly not devoid of elephants' bones.

Upon adding to all these places the shores of the Kolyma and the Anadir, spoken of by Pallas, we shall find that there is not a spot in Siberia which does not contain elephants' bones. But what will appear, without doubt, still more extraordinary than all we have related, is, that of all places in the world, certain islands in the Frozen Sea, to the north of Siberia, contain the greatest quantity of elephants' and other bones.

The island which is nearest to the continent is 36 leagues long. "The whole island," says the editor of Billing's Voyage, " with the exception of three or four small rocky mountains, is a mixture of sand and ice; so that when a thaw melts a part of the shore, abundance of teeth and bones of the mammont are found.

" All the island," he adds, "according to the expression of the engineer, is formed of the bones of this extraordinary animal, of horns and craniums of the buffalo, or of an animal resembling it, and some rhinoceros' horns." This is certainly a very exaggerated description, but it proves how very abundant these bones are.

Another island, five leagues further off than the former, and 12 leagues long, has also plenty of teeth and bones; but a third, at 25 leagues to the northward, showed none of them.

It may be that the south of Asia furnishes these bones in as great abundance as the north.

The most southern parts of Asia hitherto found to con$\mathrm{U} 3$ tain 
tain fossil elepirants' bores rre, the sea of Aral and the shores of the Juxartes. Dauhenton mentions a petrified fragment of a grinder from the shores of this lake; and Pailas asserts that the people of the country bring to market ivory from the neighbourhood of this river.

In general it may be remarked, what is very singular, that none of these bones are dug up in such climates as we know to be inhabited by elephants at the present time, while they are so common in latitudes where they could not exist at present.

Have none of them been ever buried in the latter places? Has heat decomposed them ? or, when they have been discovered, have they been neglected, from being ascribed to the animals of the country, and nothing extraordinary observed about them? Naturalists who intend visiting the torrid zone, have a very important subject of inquiry before them.

It would seem, at least, that fossil bones have been seen in Barbary, where there are no elephants of any kind at the present day.

Without mentioning the giant's tooth seen by saint Anthony upon the shores of Utica, and which was as large as a hundred of the human teeth of the present day, the skeleton of the giant dug up by some Spanish slaves near Tunis, in 1559, must have been that of an elephant, more particularly as a second skeleton was dug up at the same place in 1630 , which was certainly that of an elephant, as was ascertained by Peyresc*.

In order to complete the history of fossil elephants, it is necessary to inquire if they are to be found in America, a country where no living ones have been discovered since it was known to the Europeans, and where these animals surely could not have been destroyed by the weak and small population which occupied that continent previous to its discovery by the Europeans.

Buffon has already advanced the doctrine of the existence of these bones in South America, and, as he asserts, in that 
part of it alone. We know, also, that he imagined as the eause of their extinction in that continent, the impossibility, from the place where they lived, of their passing the isthmus of Panama when the gradual increase of cold weather forced them towards the south, as if the whole of Mexico was not still warm enough for them to live in.

To conclude; the facts upon which Buffon rested his hypothesis are not entirely accurate. The bones which were discovered in America in his time were not those of the elephant; they belongcd to another animal which we have now distinguished by the name of mastodonta, and which is also known by the name of the animal of the Ohio.

But there are certainly proofs of the existence of real elephants' bones in America at this moment : several recent authors testify this. Mr. Rembrandt Peale, in his Historical Disquisition on the Mammoth, says that jaw-bones have been found in Kentucky completely similar to those of Siberia, but in small number, in a state of decomposition, and unaccompanied with other bones; whence he concludes that the extirpation of the elephant in this continent was long previous to that of the mastodonta or animal of the Ohio, or that its carcase was brought there by some catastrophe.

I find a true elephant's jaw, very well represented, in a plate of the work of J. Drayton upon Carolina.

Catesby speaks of some real fossil elephant teeth in this country. "In a part of Carolina called Stono were dug up three or four teeth of a large animal, which all the negroes, who were natives of Africa, declared to be elephants' grinders; and I thought so myself also, having seen some similar ones which had been brought from Africa*."

Mr. Barton, who pointed out this passage to me, remarks, with truth, that it ought not to be inferred that these teeth were precisely similar to those from Africa, but merely elephants' teeth in general : I should here say, teeth composed of lamina. In fact, we cannot suppose that Catesby and his

* Catesby's History of Carolina, vol. ii. App. p. 7.

U 4

negroes 
negroes were fit to distinguish the species of this genus at a period when no naturalist had as yet disringuished them.

Mr. Barton adds, that he has himself seen some teeth of the European fossil elephant found, in 1795, at some distance to the north of the place spoken of by Catesby, at a place called Biggin-swamps, near the source of the west branch of Cooper river. They were eight feet deep, mixed promiscunusly with bones of the great mastodonta.

The same gentleman saw a grinder of this description procured from a branch of the river Susqueanna, with a portion of a tusk six feet long and 31 inches round, which would have been at least ten feet long if it had been entire; and, what is remarkable, the Delaware savages call this branch Chemung, or Horn river.

It was according to these facts that Mr. Barton wrote to M. Lacepede. "The skeletons or bones of some large animals, more or less allicd to the family of elephants, have also been discovered in lifferent parts of North America. Among these I recognise the grinders of a species which, if not the same as the elephant of Asia, must have been (as to the form of its grinders at least) more nearly allied to that species than is the mammoth *." Mr. Barton here means the mastodonta.

I have some pieces of fossil bones from America in my own possession. I am indebted for them to the friendship with which $I$ am honoured by M. Humboldt. During all his travels, he neglected no opportunity of collecting fossil carcases, with the view of furthering my researches; and he sent me, upon his return, two pieces of real elephants bones, the one from North and the other from South America.

The first consists of separate laminæ of grinders, and is consequently unequivocal. They are very large, and entirely similar to those of Siberia by the straightness and the small degree of festooning in the lamina of the enamel, as well as by the small dilatation of their middle. This specimen came from Mexico.

* See Philosophical Masazine, vol. xxii. p. 98. 
The other piece is a point of a tusk of calcined ivory, but completely recognisable : it comes from the province of Quito, in Peru. This tusk was less compressed than the tusk of the mastodonta is at present, and $I$ have every reason to believe that it belonged to an elephant.

I shall carefully deposit in the museum these two precions pieces, which prove that the true elephants of antiquity, with grinder teeth composed of thin laminæe, have also left their carcases to the north and sonth of the isthmus of $\mathrm{Pa}$ nama.

That we may neglect no information on the subject, we have to mention the stories told us by the Spaniards of the giants' bones found in Mexico and Peru. We may find extracts of these fables, accompanied with new and detailed accounts, in the "Gigantologie Espagnole," by Torrubia the Franciscan.

What hinders us from applying all these details to the elephant is, that they may owe their origin to the bones of two mastodontes, which are much more common in America than those of the elephant; and no person who has transmitted these details has taken the trouble of giving drawings, or has said any thing that might lead us to distinguish the species. It is true, however, that their pretended giants are now completely extirpated.

This enumeration of the places where the fossil bones of elephants have been found, is the result of an investigation which our anatomical labours, properly so called, have not permitted us to render so complete as we could have desired. It is probable that our enumeration would have been much more voluminous if we could have spared time to go over more carefully the works of naturalists and travellers, or the philosophical journals. It is, however, already sufficient to give an idea of the prodigious quantity of these bones which the earth contains, and of what may be yet discovered if such researches are continued, and if they were oftener directed by men of science. 